\title{
Analysis of the Genetic Stability of Banana Tissue Culture Propagated Plantlets cv. Ney Poovan (AB) Using Morphological and Molecular Markers
}

\author{
D. Bhalang ${ }^{1}$, G. Prabhuling ${ }^{3}$, K. Hipparagi ${ }^{1}$, S. Raghavendra ${ }^{2}$, \\ D.P. Prakash ${ }^{4}$ and A.G. Babu ${ }^{2}$ \\ ${ }^{1}$ Department of Fruit Science, ${ }^{2}$ Department of Basic Sciences and Humanities (Biochemistry), \\ College of Horticulture, UHS, Bagalkot, Karnataka, India \\ ${ }^{3}$ Directorate of Research, UHS, Bagalkot, Karnataka, India \\ ${ }^{4}$ Department of Fruit Science, College of Horticulture, Munirabad, Koppal dist., \\ Karnataka, India \\ *Corresponding author
}

\section{A B S T R A C T}

The present study was carried out to monitor somaclonal variations of banana cv. Ney Poovan (AB) during micropropagation using random amplified polymorphic DNA (RAPD). Sword suckers were used as explants and regenerated on MS media

\section{Keywords}

Somaclonal variations, BAP, Kinetin, TDZ, Phenotypic appearances, Genetic stability

\section{Article Info}

Accepted:

10 December 2017

Available Online:

10 January 2018 supplemented with BAP alone, BAP + Kinetin and TDZ at varying levels of concentrations. The regenerated shoots were again subcultured on MS medium fortified with plant growth regulators at different concentrations. Rooting was obtained on $1 / 2 \mathrm{MS}$ medium supplemented with $2.00 \mathrm{mg} / \mathrm{l}$ IBA and $2 \mathrm{~g} / \mathrm{l}$ of activated charcoal. Rooted plantlets were observed visually for phenotypic appearances and then transferred in greenhouse for hardening. After one month the hardened plants of banana were screened for genetic stability using RAPD primers. For molecular analysis 6 operon primers were used and all of them showed amplification. 04 primers (OPC 04, OPC 20, OPK 14, OPM 12) amplified unambiguous, readable and showed monomorphic bands, whereas, 02 primers (OPB 04 and OPD 07) gave polymorphic banding patterns. A total of 296 scorable band classes were produced by 6 RAPD primers tested in banana cv., Ney Poovan. The number of bands for each primer varied from 28 to 80 with an average of 49.33 bands per primer. The results obtained using RAPD showed recordable monomorphic and polymorphic band patterns. RAPD had shown $94.10 \%$ monomorphism and $5.90 \%$ polymorphism. In the present investigation, the percentage of polymorphism was $5.90 \%$ which is under permissible limit. In banana, up to $10 \%$ variation is permitted (as practiced by commercial micropropagation outfits) owing to the flexible genetic make-up of the crop.

\section{Introduction}

Bananas (Musa spp.) represent one of the most important crops in the world as well as India which is known as fruit of tropics (Purseglove,
1988). Banana and plantains together rank as the fourth most important food commodity in the world only after rice, wheat, milk or milk products (Amar, 2000). In vitro micropropagation has several advantages which 
include high rates of multiplication, the small space required to multiply large numbers of plants in a short duration, production of diseases free planting material and the homogeneity of their growth.

True to type clonal fidelity is one of the most important prerequisites in the micropropagation of any crop species. Appearance of off-types during the in vitro multiplication process is an important drawback for mass propagation of bananas.

The types of cytokinins, concentrations, their combinations and type of banana cultivars significantly influences regeneration of morphological abnormal plants (Arinaitwe et al., 2000; Gubbuk and Pekmezci, 2004). Whereas, some researchers (Vuylsteke et al., 1991; Martin et al., 2006) reported that the extent of instability in Musa was found to depend on the interactions between the genotype and the tissue culture conditions.

The in vitro multiplication of plants involves the application of plant growth regulators and changes to these phytohormone habituations are known to be associated with genetic instability in plants. Somaclonal variation in tissue culture is a common phenomenon, which makes it mandatory to check the genetic stability of in vitro raised plants. The genetic integrity of the micropropagated plants may lead to changes either in the phenotype or the genotype that can be determined with by different techniques. These variations are often undesirable, but still heritable (Brieman et al., 1987).

Presently, there are various methods available which can be used to detect the tissue culture derived somaclonal variants. The most reliable methods are the molecular marker techniques that identify the variance depending on the plant proteins, which are expressed from defined regions of DNA, or DNA polymorphisms. RAPD (random amplified polymorphic DNA's) is a powerful technique for identification of genetic variation (Welsh et al., 1990). It has the distinct advantage of being technically simple and quick to perform, requiring only small amounts of DNA. Hence in the present study, RAPD were used to analyze the genetic stability of plantlets that were produced through tissue culture and compared with the genetic constitution of the mother plant.

\section{Materials and Methods}

The banana plants used in the present study was Musa paradisica cv. Ney Poovan (AB). The experiments were conducted at the Centre for Horticulture Biotechnology, Directorate of Research, University of Horticultural Sciences, Bagalkot, during 2016-17. Sword suckers were used as explants and regenerated on MS media supplemented with BAP alone (at 5,6,7,8 mg/l), BAP + Kinetin (at 5+1, 6+1, $7+1,8+1 \mathrm{mg} / \mathrm{l}$ ) and TDZ (at 0.20, 0.40, 0.60, $0.80,1.00 \mathrm{mg} / \mathrm{l})$. Two subculturing was carried out every after 30 days of inoculation.

Separated elongated shoots were inoculated on $1 / 2$ strength of MS medium supplemented with $2.0 \mathrm{mg} / \mathrm{l} \mathrm{IBA}$ and $2 \mathrm{gm} / \mathrm{l}$ activated charcoal for rooting. The rooted plantlets were observed visually for phenotypic appearances and then transferred in greenhouse for hardening. The hardened plantlets were again observed visually for phenotypic appearances viz., normal, subnormal and abnormal plantlets. They are identified on the basis of the following criteria:

\section{Normal plantlets}

These were sturdy, green, taller than subnormal and abnormal plantlets, in good health, having alternate leaf arrangement with better leaf area and having well developed roots. 


\section{Subnormal plants}

These plantlets were shorter than the normal plantlets but taller than abnormal plantlets, having thinner shoots, poorer leaf area with poorer root development.

\section{Abnormal plantlets}

These plantlets were having more number of adventitious buds during multiplication, stunted growth, very thin shoot, very poor leaf and root development during multiplication as well as hardening stages.

\section{Molecular analysis of plantlets}

The hardened plants were then screened genotypically and compared with the mother plant for genetic stability using 10 RAPD markers.

\section{Preparation of template DNA}

DNA sample was extracted from the leaf of mother plant as well as tissue cultured multiplied plantlets. Two hundred $\mathrm{mg}$ of young leaves were collected. The leaves were first washed with distilled water and these leaf samples were used immediately for extraction or stored at $-20^{\circ} \mathrm{C}$ for short term, for future use. These fresh leaves were ground to fine power with liquid nitrogen in a mortar and pestle.

The powder was transferred to a $50 \mathrm{ml}$ sterile polypropylene tube containing $5 \mathrm{ml}$ of extraction buffer $(200 \mathrm{mM} \mathrm{NaCl}, 25 \mathrm{mM}$ EDTA, 200mM Tris-HCl, pH 8.0, 0.5\% SDS, $0.2 \%$ (v/v) $\beta$ mercaptoethanol (BME), $0.2 \%$ (v/v) Bovine serum albumin and $1 \%$ polyvinyl pyrrolidone (PVP). Banana being high polyphenol containing plant, additional measure was adopted in the extraction buffer with addition of BME and PVP. The homogenate was centrifuged at $10000 \mathrm{~g}$ for 10 minutes. To the supernatant, equal volume of phenol: chloroform: isoamyl alcohol (25:24:1) was added and centrifuged at $10000 \mathrm{~g}$ for 10 minutes. The DNA was precipitated from the aqueous phase by mixing with an equal volume of isopropanol and kept at $20^{\circ} \mathrm{C}$ overnight followed by washing with $70 \%$ ethanol. The DNA pellet was then air dried and resuspended in sterile distilled water. The RNase treatment at a concentration of $1 \mathrm{mg} / \mathrm{ml}$ was given by incubating the solution at $37^{\circ} \mathrm{C}$ for 20 minutes. The quality and quantity of purified total DNA was estimated by taking absorbance at 260 and $280 \mathrm{~nm}$ using Nanodrop Spectrophotomer (NanoDrop 1000 spectrometer, Thermo Scientific Corp., USA). The DNA was then separated on $0.8 \%$ agarose gel using ethidum bromide and photographed in a Gel Documentation System.

\section{RAPD analysis}

A total of 10 RAPD markers were used to assess the genetic fidelity of plantlets with the mother plant.

\section{Results and Discussion}

Phenotypic appearance of plantlets at the end of rooting stage, primary and secondary hardenings

At the end of rooting stage, the plantlets exhibited different kinds of responses viz., normal (+), subnormal (++) and abnormal $(+++)$ (Table 1 and Plate 1). All the plantlets derived from the MS Basal media without hormone, BAP ( $T_{2}$ to $T_{5}$ ) alone at different concentrations and BAP with kinetin $\left(\mathrm{T}_{6}\right.$ to $T_{9}$ ) at varying levels showed normal growth. Whereas, those plantlets derived from TDZ supplemented media exhibited both subnormal $\left(T_{10}, T_{11}\right.$ and $\left.T_{12}\right)$ as well as abnormal $\left(T_{13}\right.$ and $\mathrm{T}_{14}$ ) phenotypic appearances with stunted growth, thinner shoots and abnormal adventitious buds. 
All the plantlets which appeared to be subnormal and abnormal during multiplication as well as after rooting stages could not revert back to normal plantlets upon primary and secondary hardening (Table 1 and Plates 2, 3).

Assessment of genetic stability of micropropagated plants using Randomly Amplified Polymorphic DNA (RAPD) marker

It was difficult to distinguish the somaclonal variants from the normal plants using traditional morphological markers. Random amplified polymorphic DNA markers (RAPD) were, therefore, used in the present study to determine the genetic variation among the in vitro regenerated plantlets. For molecular analysis 10 operon primers were used and 6 of them showed amplification. 04 primers (OPC 04, OPC 20, OPK 14, OPM 12) amplified unambiguous, readable and showed monomorphic bands, whereas, 02 primers (OPB 04 and OPD 07) gave polymorphic banding patterns. A total of 296 scorable band classes were produced by 6 RAPD primers tested in banana cv., Ney Poovan. The number of bands for each primer varied from 28 to 80 with an average of 49.33 bands per primer. The results obtained using RAPD showed recordable monomorphic and polymorphic band patterns. RAPD had shown $94.10 \%$ monomorphism and $5.90 \%$ polymorphism. Samples with monomorphic and polymorphic band classes obtained from cultivar 'Ney Poovan' is shown in Table 2 and Plates 4, 5, 6, 7.

Phenotypic appearance of plantlets at the end of rooting stage, primary and secondary hardenings

In the present investigation, all the planlets derived from MS B without hormone (Control), BAP treated media as well as a combination of BAP and $\mathrm{Kn}$ appeared to be phenotypically normal. The present study was in agreement with the finding of Ray et al., (2006). They reported that there was no morphological variation among the regenerated clones during in vitro micropropagation with BAP, acclimatization and transfer to the field conditions.

The plantlets derived from full strength MS Basal media supplemented with TDZ 0.02, 0.04 and $0.06 \mathrm{mg} / \mathrm{l}$ appeared to be subnormal. Whereas, the plantlets derived full strength MS Basal media containing TDZ 0.08 and $0.10 \mathrm{mg} / \mathrm{l}$ were abnormal in appearance. The phenotypic appearance of these off-types include stunted growth, thinner shoots, production of more number of abnormal adventitious buds. It is evident that the appearance of phenotypic variant plants is attributed to the inhibitory effects of TDZ at higher concentrations. Huetteman and Preece (1993) stated that thidiazuron (TDZ) may inhibit shoot elongation. Lee (2005) reported that at higher concentration of TDZ $(9.1 \mu \mathrm{M})$, elongation of shoots was inhibited and clumps of small globular buds appeared at the base of shoots. Farahani et al., (2008) observed that with high concentrations of TDZ the number of normal shoots were reduced and abnormal shoots were observed. Strosse et al., (2008) stated that in contrast to BAP being the most effective at high concentrations, TDZ should be applied at lower concentrations. Also, Shirani et al., (2009) reported that cultivars having ' $\mathrm{B}$ ' as one of its genomic constitutions are more sensitive to higher concentrations of TDZ as compared to BAP. Arinaitwe et al., (2000) reported that at $16.8 \mu \mathrm{M}$ equimolar concentrations shoot proliferation on TDZ supplemented media was manifested by the appearance of numerous fleshy bulbous structures each of them producing several stunted tiny adventitious buds on their surfaces. This high cytokinin activity of TDZ has been reported by several workers (Thomas and Katterman, 1986; Fellman et al., 1987; 
Mok et al., 1987). This behavior is attributed to TDZs ability to accumulate endogenous cytokinins in cultured tissues (Huetteman and Preece, 1993) (Fig. 1-3).

\section{List of primers for screening}

\begin{tabular}{|l|l|l|}
\hline Sl. No. & Primers & Nucleotide sequence $5^{\prime}-3^{\prime}$ \\
\hline 1 & OPB 04 & GGACTGGAGT \\
\hline 2 & OPC 04 & CCGCATCTAC \\
\hline 3 & OPC 20 & ACTTCGCCAC \\
\hline 4 & OPD 07 & TTGGCACGGG \\
\hline 5 & OPK 14 & CCCGCTACAC \\
\hline 6 & OPM 12 & CACAGACACC \\
\hline 7 & OPA 20 & GTTGCGATCC \\
\hline 8 & OPC 02 & GTGAGGCGTC \\
\hline 9 & OPC 08 & TGGACCGGTG \\
\hline 10 & OPN 10 & ACAACTGGGG \\
\hline
\end{tabular}

Table.1 Effect of Cytokinins on phenotypic appearance of in vitro regenerated plantlets of banana cv. Ney Poovan (AB)

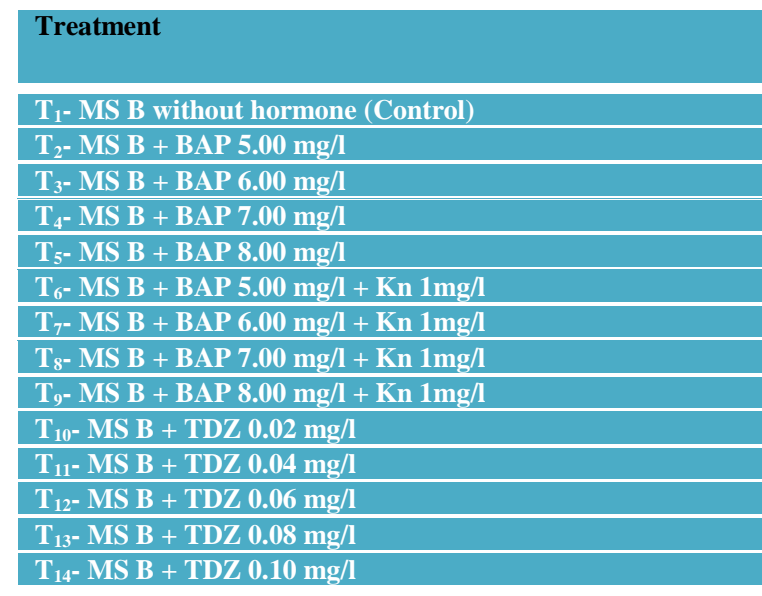
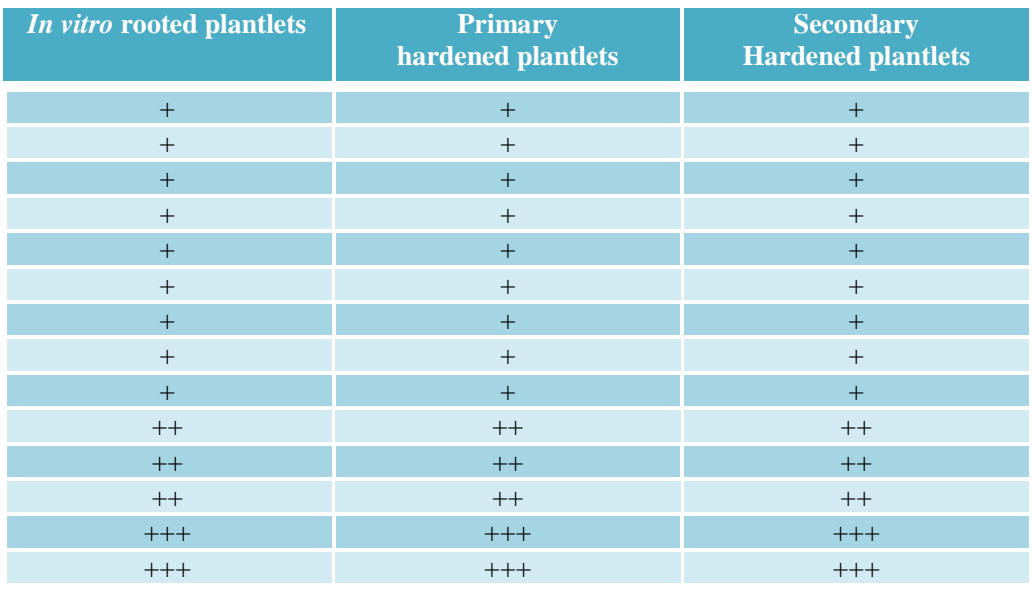

$+=$ Normal plantlets; $++=$ Subnormal plantlets $;+++=$ Abnormal plantlets

Table.2 Comparative RAPD analysis on in vitro derived plantlets regenerated by different concentrations of Cytokinins and mother plants of banana cv. 'Ney Poovan'

\begin{tabular}{|c|c|c|c|c|c|c|}
\hline Primers & $\begin{array}{l}\text { Nucleotide sequence } \\
\qquad 5^{\prime}-3^{\prime}\end{array}$ & $\begin{array}{c}\text { Number of } \\
\text { monomorphic } \\
\text { bands }\end{array}$ & $\begin{array}{c}\text { Number of } \\
\text { polymorphic } \\
\text { bands }\end{array}$ & $\begin{array}{c}\text { Total } \\
\text { number of } \\
\text { bands }\end{array}$ & $\begin{array}{c}\text { Per cent } \\
\text { Monomorphism }\end{array}$ & $\begin{array}{c}\text { Per cent } \\
\text { Polymorphism }\end{array}$ \\
\hline OPB 04 & GGACTGGAGT & 65 & 15 & 80 & 81.25 & 18.75 \\
\hline OPC 04 & CCGCATCTAC & 42 & 0 & 42 & 100 & 0 \\
\hline OPC 20 & ACTTCGCCAC & 56 & 0 & 56 & 100 & 0 \\
\hline OPD 07 & TTGGCACGGG & 40 & 8 & 48 & 83.33 & 16.67 \\
\hline OPK 14 & CCCGCTACAC & 42 & 0 & 42 & 100 & 0 \\
\hline OPM 12 & CACAGACACC & 28 & 0 & 28 & 100 & 0 \\
\hline Total & & 273 & 23 & 296 & 564.58 & 35.42 \\
\hline Average & & 45.50 & 3.83 & 49.33 & 94.10 & 5.90 \\
\hline
\end{tabular}



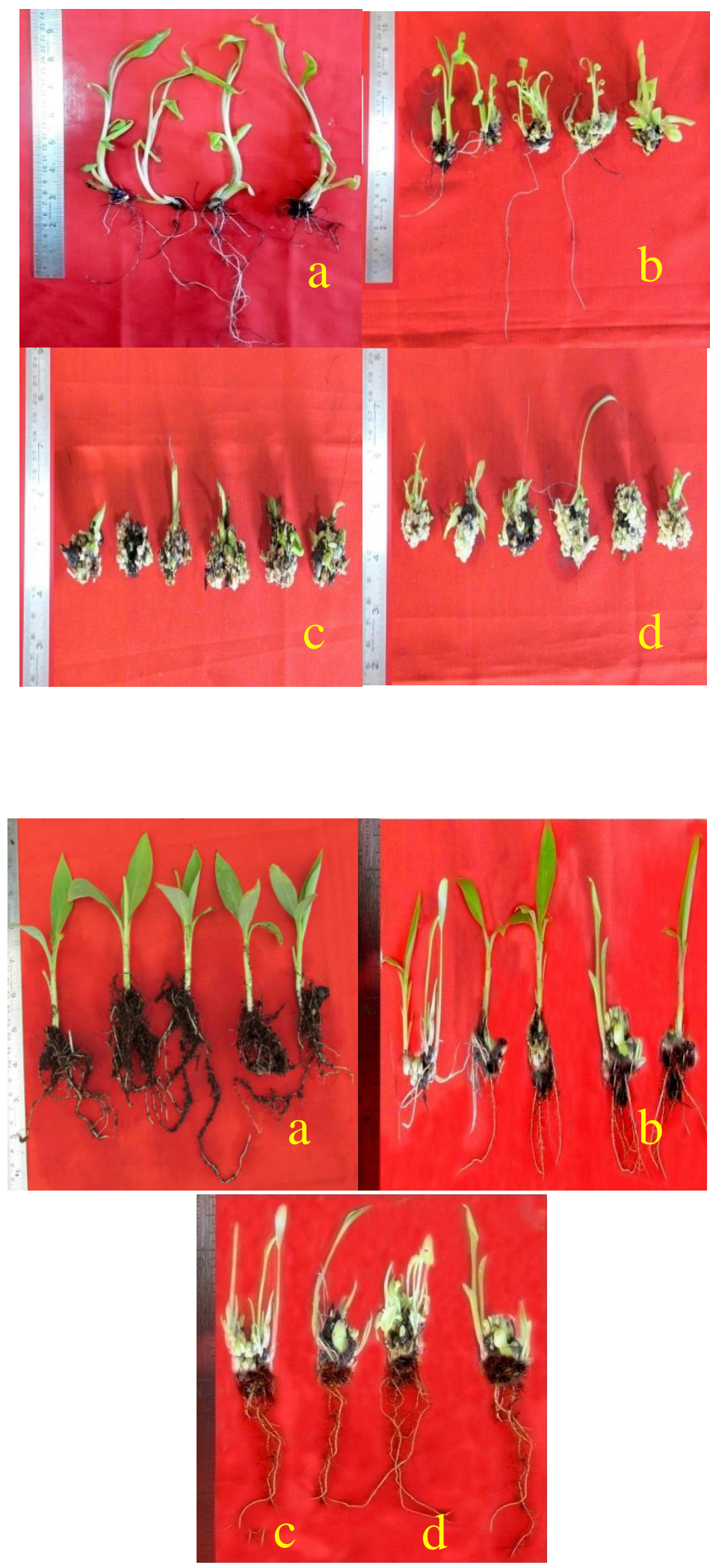

Fig.1 (a-d) Phenotypic appearance of in vitro rooted plantlets of banana cv. Ney Poovan (AB)

a) Normal plantlets obtained from MS B without hormone (Control)

b) Subnormal plantlets obtained from MS B + TDZ $0.06 \mathrm{mg} / \mathrm{l}$

C) \& d) Abnormal plantlets obtained from MS $\mathrm{B}+\mathrm{TDZ} 0.08$ and TDZ $0.10 \mathrm{mg} / \mathrm{l}$
Fig.2 (a-d) Phenotypic appearance of plantlets of banana cv. Ney Poovan (AB) after primary hardening

a) Normal plantlets obtained from MS B without hormone (Control)

b) Subnormal plantlets obtained from MS B + TDZ $0.06 \mathrm{mg} / \mathrm{l}$

C) \& d) Abnormal plantlets obtained from MS B + TDZ 0.08 and TDZ $0.10 \mathrm{mg} / \mathrm{l}$ 

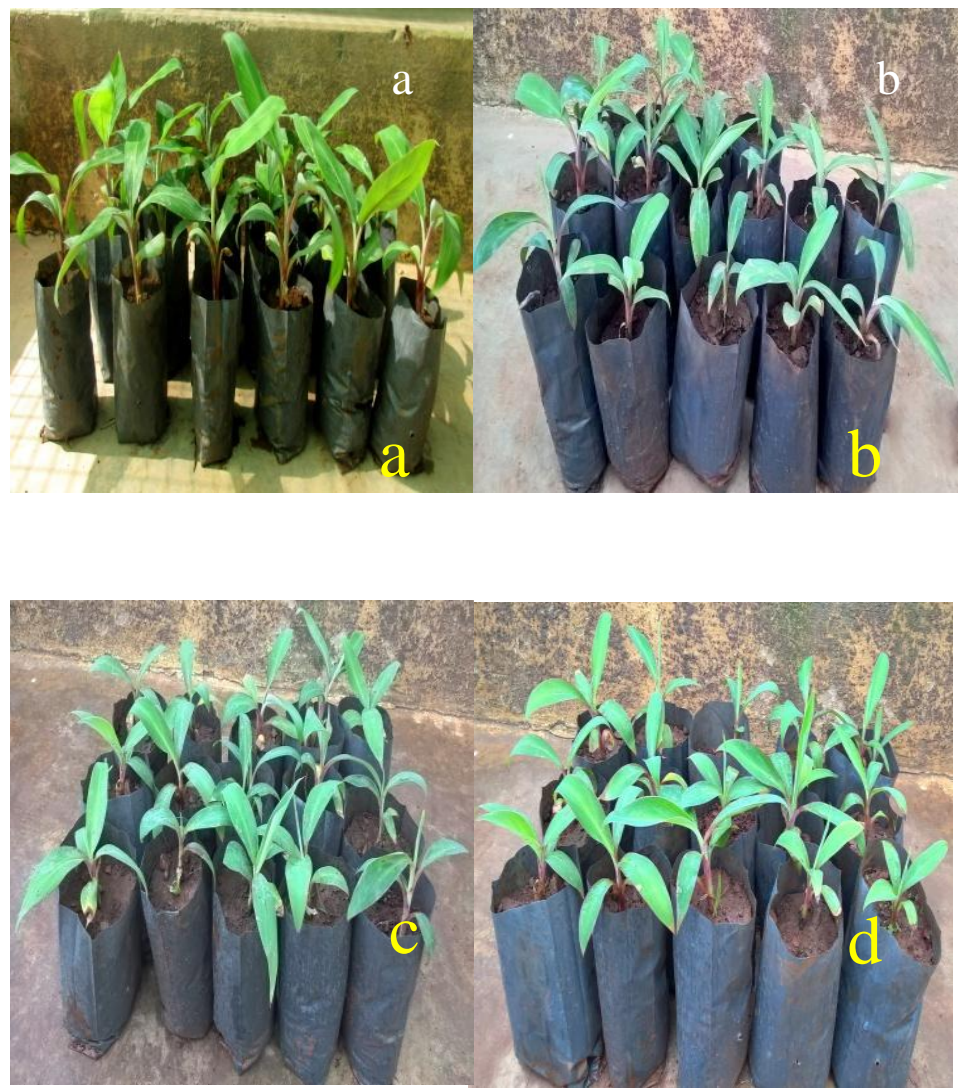

Fig.3 (a-d) Phenotypic appearance of plantlets of banana cv. Ney Poovan (AB) after secondary hardening

d) Normal plantlets obtained from MS B without hormone (Control)

e) Subnormal plantlets obtained from MS B + TDZ $0.06 \mathrm{mg} / \mathrm{l}$

f) \& d) Abnormal plantlets obtained from MS $\mathrm{B}+\mathrm{TDZ} 0.08$ and TDZ $0.10 \mathrm{mg} / \mathrm{l}$

Plate.4 RAPD profile of mother plant and plantlets obtained with OPC 04

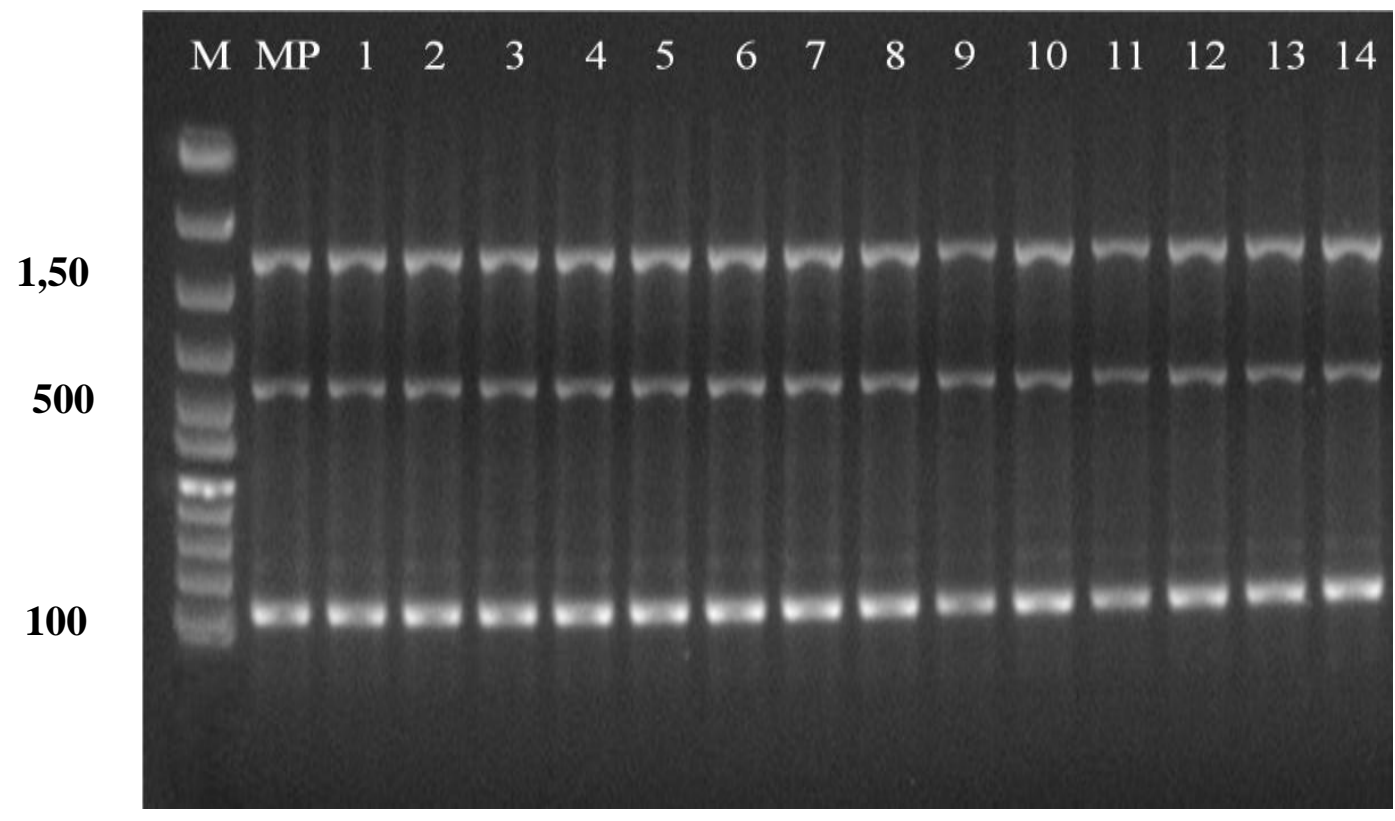


Plate.5 RAPD profile of mother plant and plantlets obtained with OPC 20

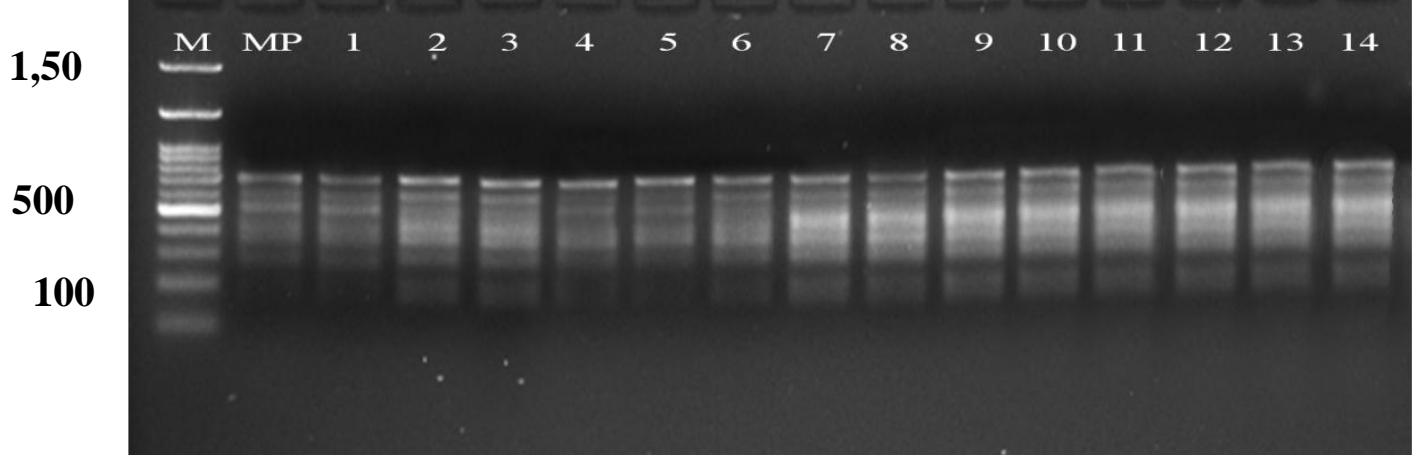

Plate.6 RAPD profile of mother plant and plantlets obtained with OPK 14

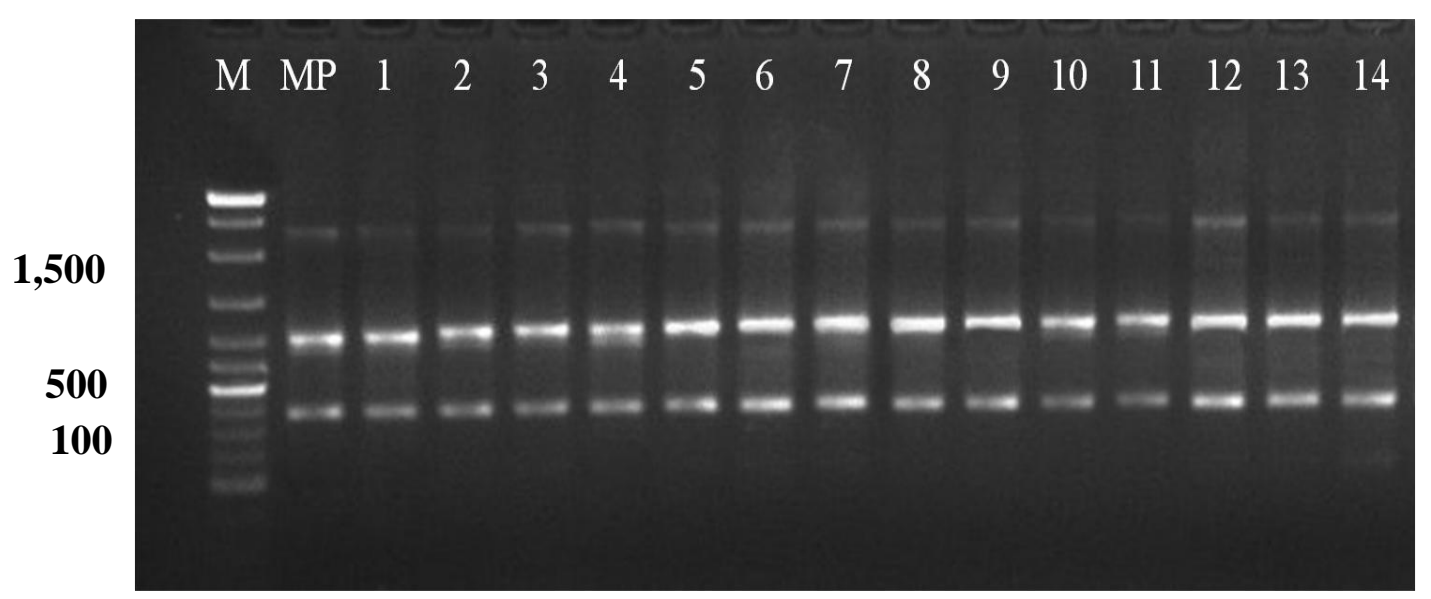

Plate.7 RAPD profile of mother plant and plantlets obtained with OPD 07

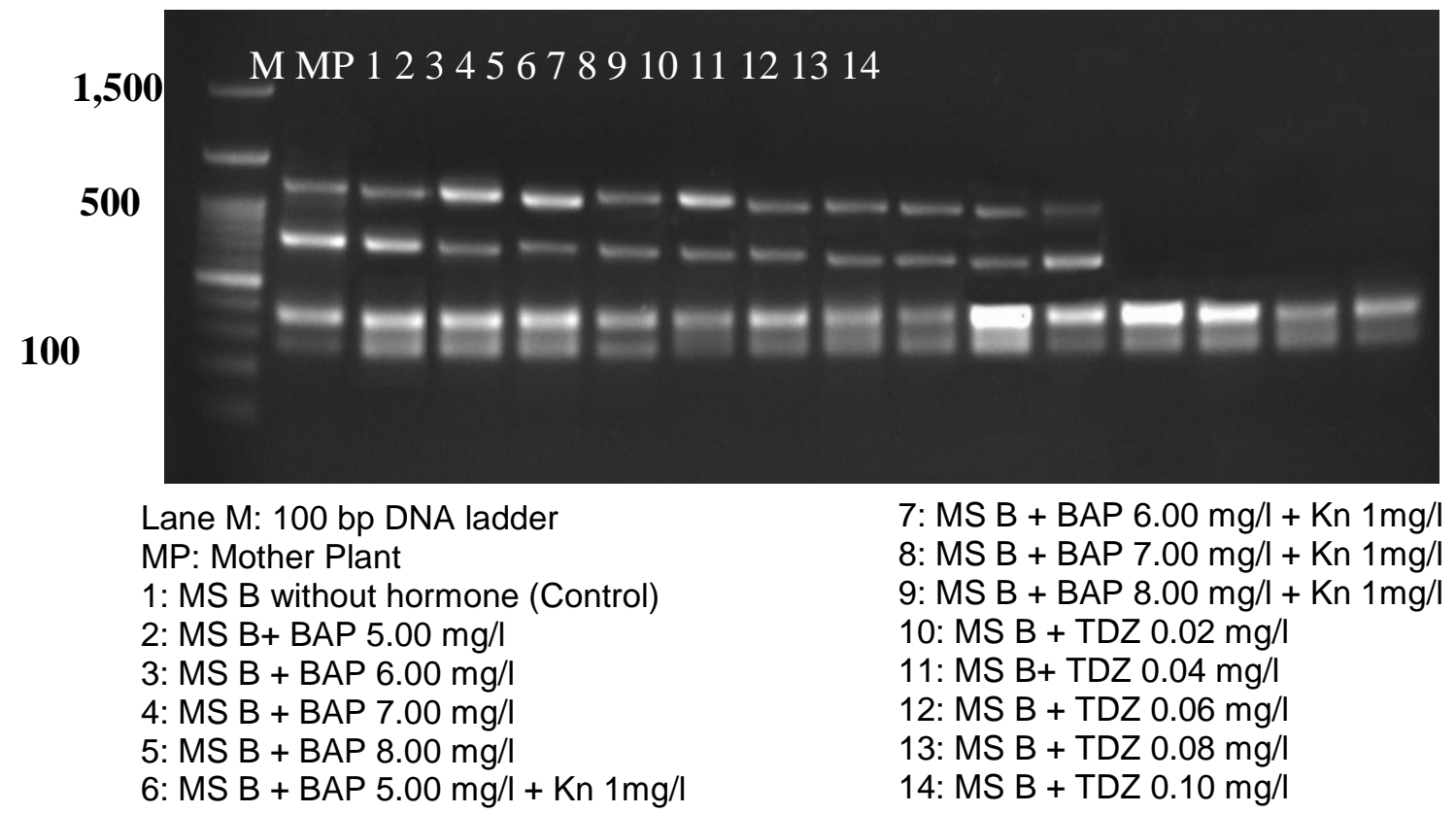


Smith and Smith (1989) opined that identification of the variants based on the morphological appearance of the plantlets does not reflect the genetic relationship. The plantlets appeared to be subnormal and abnormal during multiplication stage could not revert back to normal upon primary and secondary hardening (Table 1 and plate 2 and 3). This might be due to the reason that the present variation obtained during multiplication and rooting stages might be due to genetic variations which are caused by changes in DNA nucleotide sequence. These findings are in agreement with the reports of Ramage et al., (2004) who reported that some dwarf somaclonal variants in in vitro cultures of banana var. Williams (Cavendish banana) were relatively stable and did not generally revert to a normal phenotype with time. Vuylsteke (2001) noted that variations found in inflorescence were stable over bananas tubers and suggested that this variation is genetic in nature.

Assessment of genetic stability of micropropagated plants using Randomly Amplified Polymorphic DNA (RAPD) marker

An important problem associated with plant propagation through tissue culture is the genetic stability among sub-clones derived from the original parents. The genetic integrity of the micropropagated plants may lead to changes either in the phenotype or the genotype that can be determined with by different techniques. These variations are often undesirable, but still heritable.

The results obtained using RAPD showed recordable monomorphic and polymorphic band patterns. 04 primers (OPC 04, OPC 20, OPK 14, OPM 12) showed monomorphic bands, whereas, 02 primers (OPB 04 and OPD 07) gave polymorphic banding patterns. RAPD had shown $94.10 \%$ monomorphism and $5.90 \%$ polymorphism. Presence of negligible variation in the banding pattern of banana cv. Ney Poovan derived plants clearly indicated that the Cytokinins with high suppression of shoot growth and exudation of phenolics do not have much effect on the genetic level. In the present investigation, the percentage of polymorphism was $5.90 \%$ which is under permissible limit. In banana, up to $10 \%$ variation is permitted (as practiced by commercial micropropagation outfits) owing to the flexible genetic make-up of the crop (Smith, 1988; Cote et al., 1993).

In present study, it was observed that shoot tip derived plants were genetically identical to the sucker derived plantlets. Shoot tips, maintain strict genotypic stability under tissue culture conditions (Bennici et al., 2004), which appears applicable also to present results because little variations were observed for the primers tested which were under permissible limit. The polymorphism assessed through RAPD markers in cv. Ney Poovan clones might be due to the use of higher concentrations of TDZ. Variations observed in plantlets derived from tissue culture of cv. Ney Poovan was negligible compared to the results obtained by Grapin (1995) who reported 16-22\% somaclonal variants among plants regenerated from a 'French Sombre' suspension, whereas all plants obtained via in vitro clonal propagation were normal.

It has been reported in Musa that the extent of instability caused by in vitro culture was related to cultivar rather than the culture condition (Ray et al., 2006). Whereas, some researchers (Vuylsteke et al., 1991; Martin et al., 2006) reported that the extent of instability in Musa was found to depend on the interactions between the genotype and the tissue culture conditions. Musa cultivars exhibit differences in genetic stability, with some cultivars being more stable than others (Martinez et al., 1998). Variability in the 
presence of the A genome is high while in the presence of the B genome it is lower (Pancholi et al., 1996). The cultivar used in the present investigation belongs to $\mathrm{AB}$ genomic group with 'B' as one of its genomic constitutions revealed $5.90 \%$ polymorphism. Ventura et al., (1988) reported that micropropagation in the genome $\mathrm{ABB}$ resulted in $10.4 \%$ somaclonal variation exhibited in bunch characters (hands per bunch and atrophied fruits).

Venkatachalam et al., (2007) established that tissue culture conditions do not induce somaclonal variation in banana cv. Nanjanagudu Rasabale (AAB) as screened by RAPD markers despite exposure to high levels of cytokinins during micropropagation. Choudhary et al., (2015) reported that no polymorphism was detected during RAPD analysis of in vitro raised clones of banana cv. Robusta (AAA) indicating the genetic stability. Ray et al., (2006) highlighted the genetic stability of the micropropagated plants of three banana cv. Robusta (AAA), Giant Governor (AAA) and Martaman (AAB) by using 21 RAPD and 12 ISSR markers. Izquierdo et al., (2014) obtained 27 bands with RAPD marker in which all are monomorphic during the genetic stability analysis of the in vitro regenerated banana cv. FHIA-18 (AAAB). Similar results were also observed by Kajla et al., (2014) in banana cv. Grand Naine using RAPD and ISSR markers.

\section{References}

Amar, K.R., 2000. Bananas international network for the improvement of banana and plantain international plant genetic resources institute. Montpellier, France, pp: 16.

Bennici, A., Anzidei, M. and Vendramin, G.G., 2004. Genetic stability and uniformity of Foeniculum vulgare Mill. regenerated plants through organogenesis and somatic embryogenesis. Plant Sci., 166: 221227.

Brieman, A., Rotemabarbanell, D., Karp, A., and Shaskin, H., 1987. Heritable somaclonal variation in wild barley (Hordeum spontaneum). Theor. Appl Genet., 74: 104-112.

Choudhary, D., Kajla, S., Poonia, A.K., Brar, B., Surekha and Duhan, J.S., 2015. Molecular assessment of genetic stability using ISSR and RAPD markers in in vitro multiplied copies of commercial banana cv. Robusta. Indian J. Biotchnol., 14: 420-424.

Cote, F. X., Sandavol, J. A., Marie, P. and Auboiron, E., 1993. Variations in micropropagated banana and plantains. Literature survey. Fruits, 48: 15-22.

Cronauer, S.S. and Krikorian, A.D., 1984. Multiplication of Musa from excised stem tips. Ann. Bot. 53: 321-328.

Farahani, F., Aminpoor, H., Sheidai, M., Noormohammadi, Z. and Mazinani, M. H., 2008. An improved system for in vitro propagation of banana (Musa acuminata) cultivars. Asian J. Plant Sci., 7 (1):116-118.

Fellman, C.D., Read, P.E. and Hosier, M.A., 1987. Effects of Thidiazuron and CPPU on meristem formation and shoot proliferation. Hort. Sci., 22: 1197-1200.

Grapin, A., 1995. Regeneration par embryogenese somatique en milieu liquide et transformation genetique par biolistique de bananiers di-et triploids. Ph.D. thesis, Montpellier, France, pp. 90.

Huetteman, C.A. and Preece, J.E., 1993. Thidiazuron a potent cytokinin for woody plant tissue culture. Plant Cell Tissue Org. Cult., 33: 105-119.

Izquierdo, H., González, M.C. and Núñez, M.C., 2014. Genetic stability of micropropagated banana plants (Musa spp.) with non-traditional growth 
regulators. Biotecnología Aplicada, 31:23-27.

Kajla, S., Poonia, A.K., Kharb, P. and Duhan, J.S., 2014. Role of biotechnology for commercial production of fruit crops in biotechnology: Prospects and applications, edited by Salar, R.K., Gahlawat, S.K., Siwach, P. and Duhan, J.S., (Springer, New Delhi), pp. 127142.

Lee, S.W., 2005. Thidiazuron in the improvement of banana micropropagation. The Second International Symposium on Biotechnology of Tropical and Subtropical Species. 5-9 Nov. Taipei, Taiwan, Republic of China. pp. 1-11.

Martin, K.P., Pachathundikandi, S.K., Zhang, C.L., Slater, A. and Madassery, J., 2006. RAPD analysis of a variant of banana (Musa sp.) cultivar Grande naine and its propagation via shoot-tip culture. Cell. Dev. Biol. Plant, 42 (2): 188-192.

Martinez, O., Reyes, L. M. and Beltran, M., 1998. Chemovariability in the genus Musa: similarities and differences, Infomusa. 7 (2):16-20.

Mok, M.C., Mok, D.W.S., Turner, J.E. and Mujer, C.V., 1987. Biotechnological and biochemical effects of cytokininlike phenyl urea derivative in tissue culture systems. Hort, Sci., 22 (6): 1194-1197.

Pancholi, N. C., Wetten, A. and Caligari, P. D. S., 1996. Detection of levels of somaclonal variation in Musa using molecular markers. Meeting on tropical plants, 11-15 March, Montpellier. pp: 2.

Purseglove, J.W.C., 1976. Tropical Crops: Monocotyledons. Longmans, N.Y. pp. 273-283.

Ramage, C.M., Borda, A.M., Hamill, S.D. and Smith, M.K., 2004. A simplified PCR test for early detection of dwarf off-types in micropropagated Cavendish banana (Musa spp. AAA). Scientia Horti., 103 (1) 145-151.

Ray, T., Dutta, I., Saha, P., Das, S. and Roy, S.C., 2006. Genetic stability of three economically important micro propagated banana (Musa spp.) cultivars of lower Indo-Gangetic plains, as assessed by RAPD and ISSR markers. Plant Cell Tissue Org. Cul., 85:(1), 11- 21.

Sambrook, J., Fritschi, E. F and Maniatis, T., 1989. Molecular cloning: a laboratory manual. Cold Spring Harbor Laboratory Press, New York.

Shirani, S., Fatemeh, M. and Mahmood, M., 2009. Morphological abnormality among regenerated shoots of banana and plantain (Musa spp.) after in vitro multiplication with TDZ and BAP from excised shoot tips. African $J$. Biotechnol., 8: 5755-5761.

Smith, J.C.S. and Smith, O.S., 1989. The description and assessment of distance between inbred lines of maize. II. The utility of morphological, biochemical and genetic descriptors and a scheme for testing of distinctiveness between inbred lines. Maydica. 34: 151-161.

Smith, M. K., 1988. A review of factors influencing the genetic stability of micropropagated bananas. Fruits, 43: $219-223$.

Strosse, H., Andre, E., Sagi, L., Swennen, R. and Panis, B., 2008. Adventitious shoot formation is not inherent to micropropagation of banana as it is in maize. Plant Cell Tissue Org. Cult. 95: 321-332.

Thomas, J.C., Katterman, F.R., 1986. Cytokinin activity induced by Thidiazuron. Plant Physiol., 18: 681683.

Venkatachalam, L., Sreedhar, R.V. and Bhagyalakshmi, N., 2007. Micropropagation in banana using high levels of cytokinins does not involve 
any genetic changes as revealed by RAPD and ISSR markers. Plant Growth Regulat., 51: 192-205.

Ventura, J., De, L. C., Rojas, M. E., Year, E. C., Lopez, J. and Rodriguez, N. A. A., 1988. Somaclonal variation in micropropagated bananas (Musa spp.). Technical en la Agricultur Viandas, 11(1):7-16.

Vuylsteke, D., 1998. Field performance of banana micropropagules and somaclones. In: Jain, S.M., Brar, D.S. and Ahloowalia, B.S. (eds). Somaclonal variation and induced mutation in crop improvement. Kluwer, Academic
Publishers, Dordrecht. pp. 219-231. Vuylsteke, D., 2001. Strategies for utilization of genetic variation in plantain improvement. Ph.D. Thesis, Leuven, K.U Belgium, PP: 207.

Vuylsteke, D., Swennen, R., and De Langhe, E., 1991. Somaclonal variation in plantains (Musa spp. AAB group) derived from shoot-tip culture. Fruits. 46: 429439.

Welsh J, McClelland M. Fingerprinting genomes using PCR with arbitrary primers. Nucl. Acids Res. 1990. 18: 7213-7219.

\section{How to cite this article:}

Bhalang, D., G. Prabhuling, K. Hipparagi, S. Raghavendra, D.P. Prakash and Babu, A.G. 2018. Analysis of the Genetic Stability of Banana Tissue Culture Propagated Plantlets cv. Ney Poovan (AB) Using Morphological and Molecular Markers. Int.J.Curr.Microbiol.App.Sci. 7(01): 1007-1018. doi: https://doi.org/10.20546/ijcmas.2018.701.121 